This is a self-archived version of an original article. This version may differ from the original in pagination and typographic details.

Author(s): Taipale, Joona

Title: The Unseen, the Discouraged, and the Outcast : Expressivity and the Foundations of Social Recognition

Year: 2018

Version: Published version

Copyright: (c) 2018 Walter de Gruyter GmbH, Berlin/Boston.

Rights: $C C B Y-N C-N D 4.0$

Rights url: https://creativecommons.org/licenses/by-nc-nd/4.0/

Please cite the original version:

Taipale, J. (2018). The Unseen, the Discouraged, and the Outcast : Expressivity and the Foundations of Social Recognition. SATS: Northern European Journal of Philosophy, 19(1), 2139. https://doi.org/10.1515/sats-2017-3004 
Joona Taipale*

\title{
The unseen, the discouraged and the outcast: Expressivity and the foundations of social recognition
}

https://doi.org/10.1515/sats-2017-3004

\begin{abstract}
This article analyzes different pathologies of social affirmation and examines the grounds of social recognition from the point of view of the concept of expression. The red thread of the text is provided by Tove Jansson's fictional works, and the focus will be on three cases in particular (the magic hat, the invisible girl and the figure of the Groke). The article sets out from the phenomenological distinction between the sensible expression, on the one hand, and the expressed content, on the other. By focusing on the three cases, the article distinguishes and analyses the fundamental structures of communal life and explicates different ways in which social affirmation can be one-sided or distorted.
\end{abstract}

Keywords: social affirmation, social exclusion, expression, projection, responsiveness, phenomenology, theory of recognition, psychoanalysis, developmental psychology, Tove Jansson, the Moomin

\section{Introduction: Expressivity and social responsiveness}

Our experience of other people both builds upon sense perception and transcends it. From the outset, others stand out from inanimate objects due to their peculiar ways of movement. Their perceived movements seem to defy causality, appearing motivated and meaningful from the outset. Instead of twisted physical superficies, we see facial expressions; instead of mechanic movements, we track deliberate gestures and behavior; instead of meaningless sounds, we hear speech, tones of voice and so on. Expressions come in many guises and they can be either voluntary or involuntary. While conveying higher-order mental processes (such as thoughts, ideas and interpretations) usually requires conscious effort and articulation, the expression of spontaneously arising feelings,

*Corresponding author: Joona Taipale, The Department of Social Sciences and Philosophy, University of Jyväskylä, P.O. Box 40014, Jyväskylä, Finland, E-mail: joona.h.taipale@jyu.fi 
intentions and reactions remains largely involuntary, even unconscious, thereby necessitating no activity or approval on the part of the expressing subject. Simply put, when someone feels happy, sad, pleased or disappointed about something, his or her facial expression, glance, rhythm of breathing, posture, gait and tone of voice forthwith tend to betray this.

In everyday social life, the reception of expressions is crucial. Other people are the receivers, addressees and witnesses to our sayings and doings, which is to say that besides manifesting intentions, feelings, and moods of their own, their behaviors also reflect their attitudes toward ourselves. Reflecting the others' attitudes toward us, the expressive responses of others, voluntary or not, serve as the cornerstone of social affirmation and recognition.

The others' expressive responses and reactions to our doings and sayings harbor significant qualitative differences. In general terms, the quality of the responses varies along the axis of approving/disapproving. Approving responses range from remaining silent, instead of speaking out, when someone makes an offensive (e.g. sexist or racist) note to someone in public, to explicitly nodding and verbally congratulating someone. Likewise, disapproval can be expressed by a discrete sigh, by rolling one's eyes or by more visible and audible reactions and verbal bursts. In densely populated urban societies, where we often simultaneously have several people in our field of perception, most of the expressive feedback from others remains unnoticed, implicit or unconscious to us, and yet it greatly influences our interactions in a variety of ways. The smallest nuances make all the difference here, and social life is infinitely complex in this respect. When someone does not seem to hear us, when being asked for the time at a noisy bus station for instance, our experience is remarkably different from cases where we suspect that the other's silence and unresponsiveness is deliberate. Paradoxically, however, even explicitly disapproving expressive responses contain rudimentary seeds of social affirmation. When reacting to someone else's sayings or doings with blame, contempt or overt ignorance, for instance, we at once come to reveal that we nonetheless consider them to be something more than physical things or animate objects - after all, we would not explicitly "look through" a flock of birds or a stone, but we save and limit our expressions of disapproval to those whom we consider to be our potential social peers. In this sense, even disapproving expressive responses count as elementary forms of social affirmation and as antecedent forms of social recognition (see Honneth 2008, 151-158). ${ }^{1}$

1 The phenomenon of social recognition also has historical and cultural dimensions: the forms, subtleties and nuances of recognition vary across cultures. Considering this issue in more detail, however, would lead too far and I won't be examining this matter in the present article. 
Expressivity has a twofold structure: it comprises both the expression itself and that which is expressed. The fundamental structures of social recognition can be further elaborated in light of this distinction. Usually, acts of social affirmation target the person as an expressive unity, thus covering both sides of the phenomenon, as it were. To be sure, as was already pointed out, without a perceivable expression we could not know anything of the other's lived experiences. Yet, in fluent interaction, our conscious attention does not altogether seize upon the other's sensible expressions per se, but we are rather focused on the meaningful contents conveyed in and by them. And so, for example, instead of fixing our attention to the other's visible smile, we are rather preoccupied with his affect of joy (see Taipale 2015b). The lived body is the expression of subjectivity, as Husserl and Merleau-Ponty claim (Husserl 1952; 204, 1973; 327; Merleau-Ponty 2012; 187), and it is worth underlining here that, when perceiving other people, we usually experience the two, the expression and the expressed, as a unity.

In everyday social life, we also experience ourselves as such expressive unities. However, what is at stake here is a complex developmental achievement (see, e.g. Rochat 2004), which presupposes experiences of "being-for-others", to echo Sartre's quoted wording (see also Taipale 2013, 2014, 2016b, 2017a). As Husserl puts it: "To acquire a personality it is not enough that the subject becomes aware of itself as the center of its acts: personality is rather constituted only when the subject establishes social relations with others" (Husserl 1973, 175). The roots of such experiences reach back to early interaction, where the child's expressions find a reflective surface in the caregiver. Via countless repetitions, the child increasingly consolidates and habituates the experience that her lived experiences - her immediately felt needs, wants and interoceptive sensations (such as the sense of hunger) - are graspable from the outside, by others. In their expressive guise, lived experiences are perceivable to others, they matter socially and effect changes in the external world (e.g. give rise to gestures and reactions in the others). The development of social self-awareness begins from an extremely vulnerable state in the sense that it initially feeds on experiences of coherent expressive feedback. In short, the primary others serve as "social mirrors" for the child (see Taipale 2016c \& 2016d).

In smooth social interaction, the expression and the expressed go hand in hand. Yet, the expression and the expressed can also experientially diverge from one another in many ways. For one, the capacity to restrain and hide our spontaneous opinions, feelings and impulses from others is one of the conditions of smooth social life. To avoid unwanted social feedback, people fake, pretend, exaggerate and lie. In such cases the unity of the expression and the expressed is imbalanced, fractured or broken: instead of emerging 
spontaneously, the expression is now crafted or used to manipulate the others' take on oneself, while one's genuine opinions or authentic feelings are deliberately (and more or less comprehensively) made invisible to others. To be sure, such invisibility may also be promoted by the social setting itself. Just consider waiters at a fine-dining restaurant, whom we might strongly associate with their current social function and whom, hence, remain relatively invisible to us as persons with their own opinions and desires. Moreover, social invisibility can also unfold against one's will. For this, just consider a beggar in the street whom people habitually pass by without response (because she is "just a beggar”). Alternatively, consider cases of ethnic and sexual discrimination, where someone finds him/herself being overlooked as an individual, while being instead viewed solely either as a representative of a group of people about which the present others have prejudices or reservations (see Taipale 2016a, 2017b; cf. Salice and Taipale 2015), or as a body colored and shaped in a particular manner. What is common to all of these cases is that the person in question finds, in the expressive feedback from others, his or her existence being socially affirmed in a partial or distorted manner.

Social recognition can be partial, imbalanced or distortive also during the vulnerable period of early infancy where social self-awareness is still taking shape (see Taipale 2016b). While the caregiver signals to the child that she hears the child, the child's experience of what is socially confirmed of her depends largely on the quality of the caregiver's signal. For example, in and through his body language, a caregiver annoyed by the child's crying may come to signal to the child that the child's crying (i.e. the sensible expression) is indeed noticed, yet without signaling that the child's underlying unpleasant feeling of hunger (or whatever the cry expresses) is noticed. In favorable development, such onesided signals are not the rule. When the caregiver hears the crying, he or she mostly glances also beyond the sensible expression and assures the child that her felt plight and need (and not merely their audible and visible expression) are grasped and reacted to. Instead of building her social selfhood strongly on the basis of his or her external behavior, the child experiences an intersubjective affirmation of her spontaneous subjective experiences as well.

As long as the "two" affirmations proceed hand in hand, in good balance, the person - whether a child or an adult - is not forced to sharply distinguish between how she feels and how she appears from the outside. The firmly habituated impression that our feelings, opinions and judgments can be made visible and intelligible to others - i.e. our sense of social potentiality - is central in human interaction. This sense of social potentiality enables us to endure occasional misunderstandings and even humiliations. People are not usually devastated if someone else does not see their "point" or if someone omits or 
misinterprets their feelings. Regardless of whether they manage to convey their feelings and thoughts to the present others, people are normally "in touch" with their feelings and thoughts, and able to grasp the social potentiality of their subjectivity. That is to say, we commonly experience that our intentions can be seen and understood by others, even if the circumstances would not promote the actualization of this potentiality. In many ways, such implicit awareness is crucial for fluent social life and social self-understanding: it motivates us to open our mouth in public or, alternatively, hide our feelings and opinions when the situation so requires.

Various pathologies of social experience can be elaborated in terms of the distinction between the recognition of the expression (i.e. the body) and the recognition of what is expressed (i.e. subjectivity). The present article assumes this point of view. It distinguishes and analyses various imbalances of expressive exchange by making use of Tove Jansson's fictional works. Jansson's analyses of the different levels and dimensions of social and emotional life proceed in an eloquent manner, in delightful linguistic expression, yet with significant depth and generalizability. In what follows, I will analyze three cases, all of which discuss various features of social recognition and exclusion.

- The Unseen. The first case is found in the book, the Finn Family Moomintroll (1948). In the story, Moomintroll and other characters are playing hideand-seek. Moomintroll enters a magic hat that transforms him into a strange-looking creature. Crucially, he himself does not notice his transformation immediately, as only his external appearance has been altered. When realizing his new, altered outlook, Moomintroll tries to convince others that his external appearance is not a truthful expression of who he is, and finds himself increasingly troubled as no one seems to recognize his true self.

- The Discouraged. The second case refers to the story of the Invisible Child (1962). The short story introduces a girl who has turned invisible due to extensive psychological maltreatment. The girl is initially unable to express herself, and the others remain intrigued by her conspicuous invisibility. As things begin to improve, the girl's striking inability to play reveals that there are also problems in her sense of self. It turns out that her ethereal presence is actually a truthful expression of her inner powerlessness and silence (which is developmentally owing to the maltreatment). With the Moomins, the girl's spontaneous impulses are patiently given room to grow and strengthen, and the girl's social visibility is thus gradually restored.

- The Outcast. The third case brings us to the Groke (Mårran, Mörkö). The Groke appears in various books by Jansson, including the mentioned story of the magic hat and the Moominpappa and the Sea (1965). The Groke is a curious and lonely creature whose occasional presence is always associated 
with feelings of horror and anxiety, despite the fact that she has never hurt or harmed anyone. In one of the stories, the Groke's ghostly and uncanny condition is linked to developmental issues, but her case is crucially different from that of the invisible girl. Unlike the latter, the Groke is emphatically present, intensively felt in her need, and that proves terrifying.

By analyzing these cases of social invisibility one by one, my article demonstrates concretely how Jansson's fiction can be used to illuminate the structures of social life as well as their distortions. Systematically speaking, her work enables distinguishing between various important aspects underlying social recognition.

\section{The unseen - distorted expression and the magic hat}

The body is a natural power of expression - Merleau-Ponty

Let me begin with the case of Moomintroll's transformation. In the story, Moomintroll and others find a large and mysterious hat on top of a mountain. Unaware of its magical properties, they bring it to the Moominvalley. At one point after their discovery, the characters begin playing hide-and-seek in the Moominhouse, and Moomintroll finds a great hiding place from the hat. At this point, none of the characters knows that whatever enters the hat will be magically transformed into "something else". After a while, realizing that the others do not manage to find him, Moomintroll jumps out from the hat to surprise everyone. He remains experientially, affectively and emotionally identical: he still thinks and feels like he used to, and that others view him differently thus comes as a surprise. What Moomintroll does not notice is that, in fact, "he has transformed into strange creature. Everything that used to be roundshaped in him, was now narrow; and everything small was now large".

Even before asking his name, i.e. before wanting to know anything about him, the others impolitely note that he looks ugly. When being asked who he is, Moomintroll still does not realize what is going on, and assumes that others are just fooling around. Trying to be humorous, he laughs and responds that he is the King of California. Yet, others take him by his word and calmly introduce their names, before asking whether the King of California happens to know their 
friend Moomintroll. They clearly miss their dear friend, as he is known to them. Going along with what he interprets as shared fun, Moomintroll tells them that he does indeed know Moomintroll quite well and that they even happen to have the same birthday. After Moomintroll has humored himself for a while, the others, who are still unaware of his true identity, increasingly begin to express their contempt toward him, and eventually end up attacking and beating him.

Moomintroll's mother interrupts the violent scene and asks who the creature is. Touching his own face, Moomintroll then realizes his strange external appearance. Growing increasingly nervous and terrified about this, he tries to assure the others of his true identity, but the others do not believe him. In his utmost plight, Moomintroll turns toward his mother: "Mother, look at me carefully. You must know your own Moomin child". Mamma looks carefully and for a long time into the big scared eyes, and then says quietly: "Yes, you are Moomintroll". Importantly, immediately after that Moomintroll starts to change, and gains his familiar appearance also in the eyes of the others. "Come to my arms", says Mamma. "I will always know my little Moomin child".

The entering of the mother initiates two changes. First, like a mirror, she makes Moomintroll realize how he appears from the outside, superficially as it were. Second, she restores the visibility of his self despite the present unfavorable outlook: the mother's careful look informs Moomintroll that he is seen, affirmed and recognized as himself - first by his mother and then by others as well. That is to say, the mother's look prevents defining and typifying Moomintroll in a prejudiced manner through his external appearance; it prevents reducing him to his current external appearance, as if informing that his external appearance is not the truth of him. In short, the mother restores both his external and internal visibility.

The brief scene is rich as it touches upon various forms and dimensions of social recognition. The two changes can be compared with interactions between infants and their caregiver. As already indicated, within the expressive data, conveyed to the caregiver, two elements can be distinguished: (1) the expression itself, on the one hand, and (2) that which is expressed in and through the expression, on the other. Infants hardly distinguish between these two sides of expression from birth. In good circumstances, the caregiver coherently signals to the infant that not just her expression (e.g. crying), but also the expressed experience (e.g. hunger), is perceived. The two 'recognitions' on behalf of the caregiver thereby accompany one another, and such balanced 'mirroring' promotes favorable development.

Mirroring is not always easy. When Moominmamma first enters the scene, her attitude to her child emphasizes the former dimension. She initially exclusively pays attention - not to what or who the creature in front of her (more 
extensively) is - but to how and what the creature (presently) seems to be, how it (currently) looks, etc. (see Taipale 2015c, 2016a). Like a tired parent who fleetingly considers the baby as nothing more than a crying piece of trouble, Moominmamma at first goes along with the attitude of the others, relies on heavy typification, and judges the object solely on the basis of its momentary external appearance. With her more careful look, however, she sees beyond the temporary external appearance, discovers her child beyond what appears at the moment, and hence reveals the current external appearance (the expression) as an unfitting, disloyal and non-exhaustive representation of her son (the expressed). Moreover, as his mother thus sees the truth of him, as it were, this at once enables others to realize (or "recall") Moomintroll's true identity despite his altered and unwanted appearance. In this sense, Moominmamma serves as the primary mirror - the "precursor of the mirror", as Winnicott would put it (Winnicott 1971, 149) - which enables others in general to see him as he is, instead of reducing him to, and judging him according to, his current outlook and behavior.

Among others matters, the story nicely brings out the idea of the sedimented and partly hierarchical nature of mirroring, and underlines its relationship to social self-experience. In this case, the primary social mirror (the mother, the caregiver) makes Moomintroll visible, and by making him visible to her, she at once makes him visible to himself and to others as well.

In this case, primary mirroring is working well as it were. This is not necessarily the case, however, as the mirror can also be distorting. And this brings us to the story of the invisible child. ${ }^{2}$

\section{The discouraged - suffocated interiority and the invisible child}

Even a ghost has its ghostly body. -Husserl

Moving now to the second case, we run into a girl called Ninny. In the story, the Moomins are delivered a psychologically maltreated child who, consequently, has gradually turned invisible. When arriving at the Moominhouse, the girl

2 I have elsewhere analyzed this case in detail from another perspective (see Taipale 2016c, 2016d). 
cannot speak or otherwise express herself; the only thing visible of her is a silver bell that her horrid aunt has hung around her neck to know where she is. The aunt has finally given the girl away with the excuse of her invisibility - even if the aunt herself is clearly to blame for the child's condition (see Taipale 2016c).

The Moomins take the girl in, and things slowly start to improve: the visibility of the girl's external appearance is gradually increased. Yet, at one point they notice that she is unable to play: she is already largely visible, follows the rules of the games in an exemplary manner and does what is expected. However, she seems to play out of politeness, not for fun. Days go by and the process of improvement seems to come to a halt. The story culminates at the beach. Having grown to trust the Moomins, Ninny spontaneously shows aggression and bites Moominpappa's tail. Her face, the mirror of her true self, thereby finally becomes visible and story has a happy ending.

In the former case, Moomintroll's social invisibility owed to distorted external appearance, and nothing was wrong with respect to his inner life. Moomintroll is constantly in touch with how he feels, he constantly knows who he is, and the careful vision of his mother catches sight of that dimension without too much effort. Ninny's case is more troubled. Her ethereal external appearance is not misleading or deceiving, but the trouble rather lies in her inner life: initially there seems to be nothing to be bodily expressed. And so, even when the girl's external outlook is largely regained, she still seems empty on the inside - snuffed out, dejected, discouraged. A lot of time, trust and a homely environment is needed to rebuild the inner, to light it up.

In many ways, the case of Ninny is the opposite to that of Moomintroll. The social invisibility of Moomintroll's true self owes to his emphasized external appearance which does not meet the expectations of the others, while Ninny's social invisibility is owing to the discouraged nature of her true self. Moomintroll is reduced to his current external appearance and others are not interested in knowing anything beyond what they presently see of him. Ninny, by contrast, is not thus reduced and the others would indeed want to know her. Moomintroll's invisibility is contingent, owing to situational issues: he is invisible for the time being, relatively, not fundamentally. Ninny's invisibility, by contrast, is owing to developmental and more fundamental issues - she is visible only fleetingly and relatively, in the light of her current function (see Taipale 2016).

In the story, Ninny's troubles are owing to psychological maltreatment on two fronts. Of the sadistic aunt, the following is said:

You know, don't you, that if people are frightened often enough, they sometimes become invisible. (...) Ninny was frightened in the wrong way by a lady who had taken care of her without really liking her. I've met this lady and she was horrid. Not the angry sort, you 
know, which would have been understandable. No, she was ice-cold and ironic. (...) She was ironic all day long every day, and finally the kid started to turn pale and fade around the edges, and less and less was seen of her. ${ }^{3}$

When the inner (i.e. spontaneity, subjective creativity) develops deficiently, the outer usually tends to become emphasized - so that people, for example, tend to underline their outer achievements and possessions. On the other hand, if the outer is not appreciated and intersubjectively validated, people tend to withdraw, retreat inwards. The tragedy of Ninny is that both ways are blocked as it were. On the one hand, the horrid aunt had been emotionally unresponsive ("ice-cold") to the girl, thus suffocating her spontaneity. With the emotionally unresponsive aunt, Ninny's spontaneous reactions and impulses have found no resonance or felt attunement, as a consequence of which her basic sense of self has weakened and faded out. On the other hand, the aunt's ironic attitude had gradually discouraged Ninny, thus making her (quite literally) lose her face (Lantz 2012). Yet, given her unsolidated core, fleeing inward has not really been an option and Ninny has had nowhere to go. Hence her fundamental invisibility. Ninny has formed her sense of self while looking at a distorting mirror that reflects back nothing but a cold and lifeless thing. Looking at such a mirror, Ninny has experienced herself as being - nothing (cf. Winnicott 1971, p. 151). With the "ice-cold" aunt, Ninny's sense of self has thus gradually faded or died out, as a consequence of which she does not seem to "have any life" in her, as Little My aptly notes at one point. With the aunt, invisibility has been Ninny's best (i.e. least worst) available "alternative". In her invisibility Ninny is true to her inner void, and being without both a voice and an external appearance, the mediating figure of Too-ticky is necessarily needed to even introduce her to the Moomins in the first place.

Yet, Ninny recovers fairly easily and comprehensively. With her "new family", she gradually becomes more and more visible, and eventually learns to express her spontaneities - first in the form of aggression, then in the form of laughter - thus taking her place in the social world. It is worth noting that Ninny

3 Heinz Kohut makes a very similar remark of one of his patients, who recalls from his childhood the following destructive reaction of his mother: "he would tell her about some achievement or experience she seemed not only to be cold and inattentive but instead of responding to him at the event that he was describing would suddenly remind critically about the details of his appearance of current behaviour ("Don't move your hands while you are talking!" etc.). This reaction must have been experienced by him not only as a rejection of the particular display for which needed a confirming response but also as an active destruction of the cohesiveness of his self-experience (by shifting attention to a part of his body) just at the most vulnerable moment when he was offering his total self for approval' (Kohut, 1971, 121). 
had turned invisible with the horrid aunt, which is to say that she had been visible before. According to what has already been said above, this implies that she has experienced sufficient social affirmation and validation for a good time before the aunt's influence. That is to say, the aunt has not been Ninny's primary mirror. The question thus arises: What if the damage had happened earlier? This brings us to the uncanny character of the Groke.

\section{The outcast - an uncanny shadow called the Groke}

Moving on to the third case, we face the Groke. In comparison to Ninny, the Groke is emphatically visible. Like in Moomintroll's case, Groke's external appearance is what everyone pays attention to: they are not that much interested in what she wants, thinks or feels; everyone is rather preoccupied with the fact of her presence and manifestation. More accurately put: they are focused not on how she appears, even if this is discussed too, but they rather busy themselves with the fact that she appears and keeps appearing. When it comes to her objective features, the Groke's coldness is emphasized: the ground and plants freeze in her proximity, trees shiver and even sand seems to escape under her feet, as in one of the scenes from Moominpappa and the Sea. Yet, more loaded seems to be the fact that she makes her appearance in the first place, that she is there. Rather than being troubled by a certain kind of being, the Moomins seem troubled by the Groke's being - the focus lies not in the "ontic" but in the "ontological”, to use a Heideggerian phrasing. The Groke is not just unwanted, but the unwanted.

The Groke figures in several Moomin books. Besides the already discussed Finn Family Moomintroll (with the story of the magic hat), she participates in the events also in Moominvalley Midwinter (1957) and in Moominpappa and the Sea (1965). It is telling that, like Ninny, the Groke too is initially introduced in the Moominbooks through second-hand reports. This is in a scene of the Finn Family Moomintroll in which two small visitors Thingumy and Bob (Tofslan and Vifslan in the Swedish original) - warn the others that a horrible creature called "the Groke" is on the way to the valley. Thingumy and Bob tell that the Groke is about to steal their suitcase, which contains a huge and shiny jewel. Basing their judgment on this, the Moomins develop various ungrounded fears and prejudices concerning the Groke. When the Groke then turns up later during the night, the Moomins face her from the interiors of the Moominhouse: 
She stood immobile in front of the stairs and stared at them with her round, expressionless eyes. She was not particularly big and did not look particularly dangerous. Everyone just felt that she was terribly mean and could stand there and wait no matter how long. And that was horrible!

Rather than on first-person experiences, the Moomins base their judgment concerning the Groke on a prejudice, and this negative attitude lives on despite their judgment of the Groke's relative harmlessness.

The plot thickens as it turns out that the contents of the suitcase belong to the Groke. To settle the issue, the Moomins organize "a trial", which turns out to be just an acted-out performance of what they have already decided beforehand. The Groke is absent, she is treated as an outlaw and it is underlined that she does not need an attorney or legal representation. The story ends without the Groke getting the jewel.

Whereas the Groke here pursues the marvelous shining jewel (inside the suitcase), in Moominland Midwinter she comes after the brightness and warmth of a bonfire. She arrives and positions herself on top of the bonfire which just fades out, thus ruining the cheerful mood of the others: "She went straight to the fire. And without saying a word she sat down on it. There was a sharp hissing sound, and the hilltop was wrapped in mist". In Moominpappa and the Sea, the Groke is likewise drawn by light, this time by Moomintroll's storm lantern:

The hurricane lamp. It was out of sight behind the islands now, but she knew it was there somewhere. If it went out before she got to it, it wouldn't matter. She could wait. They would light another lamp some other evening. They always did sooner or later.

One interpretation would be to view light and warmth as emblems of love, belongingness or social inclusion. ${ }^{4}$ The Groke indeed seems to be craving light and warmth - these (should) belong to her (too). However, Moominmamma outrightly denies this, telling his son: "You should not feel pity for the Groke. You seem to imagine that she longs for everything that's alight, but all she really wants to do is to sit on it so that it'll go out and never burn again”. Moominmamma's statement of the Groke as a malicious and destructive character seems awkward. As Moominmamma herself tells others at one point, the Groke has never hurt anyone: she is feared only because she is so cold. The empirical, ontic features of the Groke, on the one hand, and the way others feel about her, on the other hand, are somehow out of balance. After all, it is repeated that the Groke is not dangerous and has never done any harm to

4 Allegedly representing the secret love of Tove Jansson and Viveca Bandler, or Tofslan and Vifslan - a link unfortunately lost in the English translation (Thingumy and Bob) - the jewel inside is what the Groke craves, and it ambiguously seems belong to her as well. 
anyone: “we're afraid of the Groke because she's just cold all over. And because she doesn't like anybody. But she's never done any harm”. The Groke seems like a negative figure who is feared not in terms of what she is, but in terms of what she lacks - e.g. what seems to bother the others in her is not the coldness per se, but the absence of warmth.

Something is clearly off in the Moomins' relation to the Groke - but what? Moominmamma, in many ways a caricature of a caring maternal figure, clearly feels uncomfortable whenever her son asks about the Groke. Her responses are short and accompanied with attempts to change the topic. When Moomintroll asks whether the Groke can talk, Moominmamma sighs, dodges the question, and says that one should not talk to her, or even about her, because "otherwise she gets bigger and starts to follow", and underlines that one "mustn't feel sorry for" the Groke. Such a recommendation from the otherwise so hospitable and caring Moominmamma is strange. Rather than malicious, the Groke seems like a burden; and yet she is treated as if she was malicious and as if their aggressive negativity toward her was justified.

The attitude of the Moomin family is heart-rending, and Moomintroll is not satisfied with his mother's assessment. Having gotten used to the Groke, he finds her to be "more of a nuisance than a danger". Against Moominmamma's advice, he feels pity for the Groke and realizes that the Groke not only is cold but also herself feels cold. During the afore-mentioned "trial", Sniff likewise feels pity, expresses his sense of injustice, weeping: "Think of how lonely she must be if she is not liked by anyone, and if she does not like anyone. Perhaps the contents of the suitcase [the jewel] is all that she has". Others do not seem interested in the feelings of the Groke at all - they treat her like an unwanted lifeless thing. The self-acclaimed judge of the jewel-trial, Snork, roars that Sniff's statement is too emotional to be taken seriously. And yet, with the same breath, in an ad hoc manner he considers the fact that the Groke is not liked by them a valid ground for an argument.

The presence of the Groke challenges the affability and kindliness of the Moomins and brings out the worst in them, as it were. Moreover, one could even speculate that the Groke is this "worst in them" - a projective figure, defensively arising from the basis of the hopes and fears of the Moomins. In other words, the Groke can also be interpreted as an "out-cast" in the psychodynamic sense: something that has been thrown or pushed outside, i.e. literally pro-jected or expressed. The Groke's projective nature is emphasized by the fact that she often makes her appearance right after others begin speaking or thinking about her. One reading here would of course be that the Groke causes their awkward feelings before they grasp her presence. In this reading, the Groke is to blame, and this is how the Moomins themselves seem to be thinking. Another 
possibility would be to think that the words or thoughts of the Moomins invoke Groke and make her appear. As we saw Moominmamma noting at one point: if one even talks about the Groke, she will get bigger. Hence, one should not talk.

The projective interpretation fits nicely with Moominpappa and the Sea, where the Groke can be seen as Moomintroll's projection vis-à-vis his father's depression. On the other hand, on the island, the behavior of the Moomins interestingly resembles the tireless behavior of the Groke: while the Moomins are searching for safety and home, Moominpappa is preoccupied with lighting up the lighthouse, which he does not manage to do until the end. Their repulsiveness of the Groke's tireless search for light and warmth can be taken as a symbol for their anxiety over their own search. It is as if they were saying: for sure, we are not like that! The common feature is that part of the self is projected onto the outside.

The Groke is like the incarnation of the inconvenient reality that one ultimately is destined to encounter, something one forcefully, even aggressively, flees into everyday routines. The Groke is somehow all the time there, outside time like the psychoanalytic "unconscious", eternally and tirelessly waiting to being invoked or reminded of

She could see the hurricane lamp at the top of the mast of the Adventure [the boat of the Moomins] quite clearly, a lonely star gliding past the last islands, all the time moving farther out towards the open sea. She gazed at it for a long time, for she was never in a hurry. Time for her was endless and passed very slowly. Time for her contained nothing, except the occasional lamps which were lit as autumn approached.

In their empathy and pity, Moomintroll and Sniff occasionally see beyond the projection. Moomintroll empathizes and even identifies with the Groke:

Moomintroll imagined he was the Groke. He shuffled along slowly, all hunched up, through a pile of dead leaves. He stood still, waiting while he spread the mist round him. He sighed and stared longingly towards the window. He was the loneliest creature in the whole world.

Yet, this proves burdensome:

It was so easy to imagine somebody who could never get warm, somebody nobody liked, who destroyed everything wherever she went. It wasn't fair. Why should he have the Groke round his neck all the time, no one else had? You just couldn't help her to get warm!

The presence of the Groke is so demanding, intensive, and consuming that the Moomins projectively judge that she causes their anxiety. Facing her takes too much energy - or, symbolically, fuel - an excuse that Moomintroll uses when needing some time off from the Groke: "I'm not going to light the lamp, it takes too much paraffin.” 
With only a few exceptions, the Groke is always met with negative emotions such as disgust, contempt or anger. Her presence is found uncanny. Her arrival is accompanied with unpleasant interruption of the familiar, habitual and routine course of life. To secure that nothing will interfere with this, the defensive solution of the Moomins is rather infantile: they flee indoors, they avoid her, and thus "close the borders", as it were. (Won't work. Sad!)

In a telling passage, Moomintroll asks his mother: "What happened to the Groke to make her like that?", "Did somebody do something to her to make her so awful?" His mother replies that "no one knows", but then wonders that it was probably rather "because nobody did anything at all", because "nobody cared for her". As if developmentally pinpointing the early origins of the done damage, Moominmamma continues: "I don't suppose she remembers anyway". Avoiding the subject, Moominmamma advises that the Groke should be treated like an obstacle: "She's like the rain or the darkness, or a stone you have to walk round if you want to get past". People want to "get past" because stopping would rupture the familiar, routine course of life.

That night the Groke was singing out on the sea. No one had come down to the beach with a lamp. She had waited and waited and no one had come. She started softly, but gradually her song of loneliness had got louder and louder. It was no longer just sad, it was defiant too. 'There's no other Groke, I'm the only one. I'm the coldest thing that ever was. I am never, never warm'.

Too-ticky, too, sees beyond the tempting projections by the Moomins. When the Groke sits on the bonfire in Moominvalley midwinter, Too-ticky's explanation is the opposite to that of Moominmamma: "She didn't come to extinguish the fire, you see, she came to warm herself, poor creature. But everything that's warm goes cold when she sits down on it. Now she's disappointed once more". Perhaps the Groke is indeed searching for light and warmth - or love, inclusion or integration - but the task appears too laborious and burdensome? Perhaps the Moomins, as welcoming and hospitable as they usually are, have just given up on her (see Korhonen 2015).

Eventually, something changes even in the Groke when she is shown care and responsivity:

Pale autumn stars had come out all over the sky. Moomintroll lay on his back looking at the hurricane lamp, but he was thinking about the Groke. If she was someone you mustn't talk to or about, then she would gradually vanish and not even dare to believe in her own existence. He wondered: perhaps a mirror might help. With lots and lots of mirrors one could see oneself in many ways, from the front and from the back, and perhaps these images might even communicate with each other. 
There was no doubt about it, the Groke was pleased to see him. She didn't mind about the hurricane lamp. She was delighted that he had come to meet her. He stood quite still until she had finished her dance. Then he watched her shuffle off down the beach and disappear. He went and felt the sand where she had stood. It wasn't frozen hard at all, but felt the same as it always did.

The Groke is delighted, and not destructive, when included. Encountering the Groke - or one's Groke - was not dangerous, and Moominmamma and the others seemed to have been wrong about her after all (Korhonen 2011). The scene from Moominpappa at Sea goes on: "Later on, a thought of the Groke crossed Moomintroll's mind. But he didn't feel that he must think about her. He would see her later as usual, but he didn't have to. Somehow he knew that she wasn't afraid of being disappointed any longer. Psychoanalytically put, Moomintroll accepts and integrates the unwanted, the unavoidable, the imperfect that he has cast defensively outside, beyond the boundaries of himself.

\section{Conclusion}

Looking at the three cases in the light of the distinctions made at the outset of the article, we may draw the following conclusions.

The first case - the Unseen - is one of accidental social invisibility. Here one remains in touch with one's lived experiences, and temporarily feels hopeless as others do not see beyond one's expressive exteriority. Like someone who is strongly typified by others, and hence not recognized as who he or she is as a person, Moomintroll is unseen by others despite his emphatic perceptual presence.

The second case - the Discouraged - is about habituated social invisibility, which is owing to dejected, suffocated and discouraged subjectivity. Unlike Moomintroll in the previous case, the invisible girl is out of touch with her lived experiences, alienated from her spontaneities. Others would want to see and know her true self, but there seems to be nothing that could be expressed, as it were.

The third case - the Outcast - is about rejected social visibility, an emphatic promotion of invisibility. The Groke embodies an intensive sense of unfulfilment, incompletion, dejection, which is represented in her tormented longing for the others' desire, acceptance and recognition. Whereas Ninny would want to remain invisible while others would want to see her, the Groke conversely would want to be seen, embraced and included, but the Moomins emphatically 
wish that the Groke would not appear. As I tried to show, this case also harbors "projective" elements. That the Groke's uncanny threatful presence is traced back to the fact that "no one bothered about her", that she is characterized "like the rain or the darkness, or a stone you have to walk round if you want to get past", and that one is advised to "talk to her, or about her, because otherwise she gets bigger and starts to chase one" - all these promote interpreting the Groke in reference to repression, negation or denial. One possibility would be to view the figure as incarnating haunting psychic dimensions (e.g. destructive, aggressive forces within oneself, the threatening possibility of losing control, the looming realization of one's finitude and mortality, the contingency of one's habitual norms and routines, etc.) that one has not properly encountered and dealt with (cf. Taipale 2015a). Hence the uncanny nature of the Groke as something that is mainly present as a threatening possibility, without ever becoming properly actualized. Being strictly kept outside the Moominhouse, beyond the boundaries of the familiar and safe course of life, the Groke is literally an outcast, a "pro-jection" or "ex-pression" of the fears and worries of the Moomins. Or, better, they each have their own "Groke".

As goes without saying, Jansson's three characters - like her books in general - allow for various interpretations. ${ }^{5}$ My aim here was to illuminate the psychological and existential depth of these three cases with the help of the theoretical sources provided by phenomenology, developmental psychology, psychoanalysis and theory of recognition. In this illumination, Jansson's characters turn out to be multidimensional and rich with meanings. What is hopefully clear from this brief discussion is the immense philosophical and psychological depth of Jansson's fiction. In this sense, her works are destined to prove intriguing to philosophically oriented minds. ${ }^{6}$

5 When it comes the Groke, Korhonen (2015) summarizes that the character has also been interpreted in terms of a "shadow" of the Moomin family (Orlov 2006) and in terms of a Kristevan “abject” (Nikolajeva 2000; Rehal-Johansson 2006; Lindberg \& Sebastian 2010). In the present context, I will not be elaborating upon these interesting connections further. For those who are interested, the source texts that Korhonen provides are Orlov, Janina (2006). "Creating the Eternal Farewell: Tove Jansson's Moomin novels”, In: Sandra Beckett and Maria Nikolajeva (eds.) Beyond Babar: The European Tradition in Children's Literature. London: Rowman \& Littlefield; RehalJohansson, Agneta (2006). "Den lömska barnboksförfattaren. Tove Jansson och Muminverkets metamorfoser”. Diss. Göteborg: Makadam; and Österlund, Mia (2002). "Muminmamma, mårra eller mymla? Moderskap, motstånd och matriarkal utopi i Mumindalen”. Naistutkimus 15:2.

$6 \mathrm{I}$ am obliged to the following persons whose feedback has significantly supported the process of writing this article: Kai Alhanen, Henrik Enckell, Sara Heinämaa, Olli-Pekka Moisio, Hans Ruin, Jussi Saarinen, Sanna Tirkkonen and Dan Zahavi. I am also grateful to the two anonymous referees appointed by the journal, whose comments were very helpful to me. This research has been generously funded by the Kone Foundation (Finland). 


\section{References}

Honneth, Axel. 2008. Reification: A New Look at an Old Idea. Joseph Ganahal, tr. Oxford: Oxford University Press.

Husserl, Edmund. 1952. Ideen zu einer reinen Phänomenologie und phänomenologische Philosophie. Zweiter Buch: Phänomenologische Untersuchungen zur Konstitution.

Husserliana Gesammelte Werke IV. Marly Biemel (ed.), Haag: Martinus Nijhoff.

Husserl, Edmund. 1973. Zur Phänomenologie der Intersubjektivität. Texte aus dem Nachlass. Zweiter Teil: 1921-28. Husserliana Gesammelte Werke XIV. Iso Kern (ed.), Haag: Martinus Nijhoff.

Jansson, Tove. 1948. Finn Family Moomintroll. E. Portch, tr. London: Puffin Books. 1950.

Originally published as Trollkarlens hatt (Helsingfors, Schildts), 1948.

Jansson, Tove. 1957. Moominland Midwinter. T. Warburton, tr. London: Sort of Books. 2017.

Originally published as Trollvinter (Helsingfors, Schildts), 1957.

Jansson, Tove. 1962. Tales from Moominvalley. T. Warburton, tr. London: Puffin Books. 1973. Originally published as Det osynliga barnet och andra berättelser (Helsingfors, Schildts), 1962.

Jansson, Tove. 1965. Moominpappa at Sea. Kingsley Hart, tr. London: Puffin Books. 1966. Originally published as Pappan och havet (Helsingfors, Holger Schilds Förlag), 1965.

Kohut, Heinz. 1971. The analysis of the self. A systematic approach to the psychoanalytic treatment of narcissistic disorders. Chicago: The University of Chicago Press.

Korhonen, Kuisma. 2011. Muumipappa ja mörkö. In Lukijoiden yhteisö, 112-132. Helsinki: Avain.

Korhonen, Kuisma. 2015. Looking through the Eyes of the Groke. Studia Culturae 25(3). 136-148.

Lantz, Pirjo. 2012. Det osynliga barnet: På spaning efter en undangömd identitet. Instinkten 3. 13-19.

Merleau-Ponty, Maurice. 2012. Phenomenology of Perception. Donald Landes, tr. London and New York: Routledge.

Rochat, Philippe. 2004. Emerging Co-awareness. In Gavin Bremner \& Alan Slater (eds.), Theories of Infant Development, 258-283. Malden, MA: Blackwell.

Salice, Alessandro \& Joona Taipale. 2015. Group-Directed Empathy: A Phenomenological Account. Journal of Phenomenological Psychology 46(2). 163-184.

Taipale, Joona. 2013. Facts and Fantasies. Embodiment and the Early Formation of Selfhood. In Rasmus Jensen \& Dermot Moran (eds.), The Phenomenology of Embodied Subjectivity, 241-262. Dordrecht: Springer.

Taipale, Joona. 2014. The Bodily Feeling of Existence in Phenomenology and Psychoanalysis. In Mirja Hartimo, Sara Heinämaa \& Timo Miettinen (eds.), Phenomenology and the Transcendental, 218-234. New York: Routledge.

Taipale, Joona. 2015a. The Anachronous Other: Empathy and Transference in Early Phenomenology and Psychoanalysis. Studia Phaenomenologica XV. 331-348.

Taipale, Joona. 2015b. Beyond Cartesianism. Body-Perception and the Immediacy of Empathy. Continental Philosophy Review 48(2). 161-178.

Taipale, Joona. 2015c. Empathy and the Melodic Unity of the Other. Human Studies 38(4). 463-479. 
Taipale, Joona. 2016a. From types to tokens: Empathy and typification. In Thomas Szanto \& Dermot Moran (eds.), Phenomenology of Sociality. Discovering the 'We', 143-158. London: Routledge.

Taipale, Joona. 2016b. Self-regulation and Beyond. Affect Regulation and the Infant-Caregiver Dyad. Frontiers in Psychology 7(889). 1-13.

Taipale, Joona. 2016c. Social Mirrors. Tove Jansson's Invisible Child and the Importance of Being Seen. Scandinavian Psychoanalytic Review 39(1). 13-25.

Taipale, Joona. 2016d. Tove Janssonin 'Näkymätön lapsi' ja sosiaalinen peilaaminen. Psykoterapia 35(1). 20-32.

Taipale, Joona. 2017a. The pain of granting otherness. Interoception and the differentiation of the object. Gestalt Theory. An International Multidisciplinary Journal 39(2-3). 155-173.

Taipale, Joona. 2017b. The Structure of Group Identification. Topoi - An international Review of Philosophy. March 2017 For an online version: http://rdcu.be/qn2C.

Winnicott, Donald. 1971. Playing and reality. London: Routledge. 